\title{
Behavior Change Communication: Family and Community Approaches
}

\author{
Tri Hastuti Nur Rochimah ${ }^{1)}$ Hajar Nur Setyowati ${ }^{2)}$ Rosyidah $^{3, a)}$ \\ ${ }^{1}$ Communication Department, Universitas Muhammadiyah Yogyakarta, Indonesia \\ ${ }^{2}$ Research and Development 'Aisyiyah National Board, Yogyakarta, Indonesia \\ ${ }^{3}$ Center For Intelligent Healthcare, Coventry University, England \\ a) author correspondence: rosyidahrosyidah29@gmail.com
}

DOI: https://doi.org/10.18196/jkm.131053

Article Info

Article history:

Received 05 Mar 2021

Revised 28 Apr 2021

Accepted 25 May

2021

\begin{abstract}
Breast and cervical cancers are two deathliest cancers causing women's death in Indonesia. 'Aisyiyah developed a model to support, educate and assist women to fight against breast and cervical cancers through behavior change communication in 15 districts. This model is implemented by integrating behavior change communication through family and community support approaches. Research on behavior change communication so far has focused more on the individual level and not many have paid attention to family (husband and wife relations) and community (cultural) factors to encourage individual behavior change. This study aims to explore 'Aisyiyah's strategies in behavior change communication (promoting, counselling, and assisting) women through family and community support approaches. This research used a descriptive qualitative method with a case study approach. Data collection are in-depth interview dan documentation. Research locations in five districts; Bantaeng, Mempawah, Sambas, Magelang, and Lamongan. This study revealed that behavior change communication integrated of promotion, family and community approaches was more effective in encouraging women to detect cancer early.
\end{abstract}

Keywords: Behavior change communication; breast and cervical cancers; early detection; family and community approach

\begin{abstract}
ABSTRAK
Kanker payudara dan serviks merupakan dua jenis kanker paling mematikan yang menyebabkan kematian perempuan di Indonesia. 'Aisyiyah mengembangkan model untuk mendorong perempuan melakukan perubahan perilaku setelah mendapatkan edukasi dengan pendekatan keluarga dan komunitas di 15 kabupaten. Model ini diimplementasikan dengan mengintegrasikan komunikasi perubahan perilaku (BCC) melalui pendekatan dukungan keluarga dan masyarakat. Penelitian komunikasi perubahan perilaku selama ini, lebih fokus pada level individu dan belum banyak yang memperhatikan factor keluarga (relasi suami istri) dan masyarkat (budaya) untuk mendorong perubahan perilaku individu. Penelitian ini bertujuan untuk mengeksplorasi strategi 'Aisyiyah dalam mendorong perubahan perilaku perempuan melalui pendekatan dukungan keluarga dan masyarakat. Penelitian ini menggunakan metode deskriptif kualitatif dengan pendekatan studi kasus. Adapun teknik pengumpulan data adalah dan wawancara mendalam dan dokumentasi. Lokasi penelitian di 5 kabupaten yaitu Bantaeng, Mempawah, Sambas, Magelang, dan Lamongan. Studi ini menemukan bahwa strategi terpadu BCC antara promosi, keluarga dan pendekatan komunitas lebih efektif dalam mendorong perempuan melakukan deteksi dini kanker Pendekatan dukungan keluarga dan masyarakat sangat penting untuk memperkuat komunikasi perubahan perilaku dalam menangani kanker payudara dan serviks.
\end{abstract}

Keywords: Deteksi dini; kanker payudara dan serviks; komunikasi perubahan perilaku; pendekatan keluarga dan komunitas 


\section{INTRODUCTION}

In recent years, the approach in social marketing has increased, especially issues related to public health, prevention, environment, community (Chichirez \& Assistant, n.d.). In this case, the social marketing approach has been implemented in various health issues such as stunting, family planning, and reproductive health, including cervical and breast cancer prevention. Referring to Aras concept, many critical social marketing applications have occurred in various fields of health promotion. Social marketing can optimize public health by facilitating relationship-building with consumers and making their lives healthier (Aras, 2011). To encourage changes in health behavior, intervention through an individual approach as the main target group (internal factor) has been quite successful, which is by conducting education and promotion intensively. Nwabichie, Manaf, and Ismail (2018) examined the approach of effect and Health Belief Model (HBM) to promote cervical cancer screening in women groups in Sisaket Province, Thailand. The HBM was developed by social psychologists Hochbaum, Rosenstock, and Kegel. This promotion of cervical cancer early detection was carried out for eight weeks, comprising training, knocking on doors, meetings, discussions, and distribution of communication materials. After implementing the program, the results showed an increase in perceptions about cervical cancer severity, prevention practices, and obstacles in screening in the target audience (Nwabichie et al., 2018).

Health Belief Model theory application to analyze behavior change was carried out in the early detection (screening) program on tuberculosis (Johari, Eslami, Alahverdipoor, Hasanzade, \& Farid, 2014). Furthermore, Maryam Johari and Ahmad Ali, in their research entitled "Behavior Change Interventions in Breast and Cervical Cancer Screening Promotion using the Health Belief Model," showed that a person's belief was related to health behavior, for example, early detection of cervical and uterine cancers. If they believed that their behavior could protect them from cervical cancer, they would carry out early detection as recommended in various cervical cancer prevention promotions. Research using HBM proved that assessing individual needs would motivate positive action in various cancer early detection (screening) programs. This study also refers to Jones et al.'s (2015) research that $\mathrm{HBM}$ is useful for analyzing perceptions, beliefs, and even barriers and benefits to increase women's participation in various cancer prevention programs through screening.

In Indonesia, the incidence of cervical and breast cancers is relatively high and tends to increase day by day. However, the number of women who carry out regular screening is incomparable to the population of women in Indonesia. The mortality rate due to cervical and breast cancer has become the highest cause of women's death than other cancers. However, there is a greater chance of recovery if women perform screening for cancer early detection. Unfortunately, $70 \%$ of women detected with these two cancers have been in the late stages, resulting in a slight chance of recovery and leading to death.

From a policy perspective, the Indonesian government has adopted an international development policy called Sustainability Development Goals (SDGs). Regarding cervical cancer prevention, it is stated in Goal 3 of SDGs in target 3.4 that by 2030, the death rate from non-communicable diseases will reduce by one-third through prevention and treatment of mental health and well-being. The Ministry of Health has been mandated to achieve this goal, stated in the Regulation of the Minister of Health of the Republic of Indonesia Number 34 of 2015 concerning the Control of Breast and Cervical Cancers, previously stated in the Technical Guidelines for Control of Breast and Cervical Cancers stipulated by the Decree of the Minister of Health Number 796/MOH/SK/VII/2010. The objectives of this policy include (a) improving the quality of life and reducing the social, cultural, and economic impacts of breast and cervical cancers on individuals, families and communities; (b) providing legal certainty in public health services and individual health services efficient and effective to manage health care and improving public health behavior, reducing public health risk factors, diagnosing and treating cases to reduce morbidity, disability and mortality due to breast and cervical cancers; (c) ensuring the sustainability of the program through the collection of data and information on the status and degree of public health as well as improving the quality of public and individual health service delivery in breast and cervical cancers; (d) expanding the coverage of mass screening to the community following the program targets set by the Minister; and (e) improving the quality of professionalism of public health officials and professionals in breast and cervical cancers in Indonesia.

Even though the government published the policy reference five years ago, the screening results were still far from expectations. Therefore, 'Aisyiyah, as a civil society organization concerned with 
various reproductive health issues, has made various efforts to educate and assist the public, especially women, to carry out screening to prevent cervical and breast cancers. Cervical and breast cancer prevention programs have been implemented from 2014 to 2020 in Bantaeng, Mempawah, Sambas, Magelang, Lamongan, and Cirebon districts, with various activities: education in the community, distribution of communication materials, use of social media, capacity building for health workers to have the ability to carry out the IVA test certified by the government, conducting training for cadres and religious leaders to conduct socialization, encouraging women to perform screening and conduct advocacy to government budgeted for the availability of infrastructure.

To encourage behavior change so that women of childbearing age perform early detection of breast and cervical cancer, 'Aisyiyah has conducted socialization using various channels. Various social media platforms are used, such as WhatsApp group, Instagram, Twitter, and Facebook. Based on target segmentation, some target audiences do not have access to social media, so face-to-face socialization is an option. From the product side, the issue of early detection of cervical and breast cancer is a big issue, requiring beyond the health knowledge because the character of the messages is taboo and is considered a private issue. Thus, face-to-face meetings with the approach of dismantling taboos on packaged messages are essential. Face-to-face meetings in the community with educational materials such as posters, films, and flipcharts are significant. In this case, "Aisyiyah uses communication media (channels) that have been existed in the community.

Encouraging behavior change to perform screening to prevent cervical and breast cancers in Indonesian society must combine various approaches. The problems in Indonesia, especially in community groups with the lowest socioeconomic status, are the challenge of changing behavior for screening access to information and services, culture, and religious interpretation. In encouraging cervical and breast cancer prevention screening, various approaches were integrated. The data on women carrying out screening during 2014-2020 are presented in the following table:

Table 1. Data of IVA, Pap smear and Breast Cancer Screenings in 2014-2020

\begin{tabular}{|c|c|c|c|c|c|}
\hline Year & IVA screening & $\begin{array}{c}\text { Pap } \\
\text { screening }\end{array}$ & smear & $\begin{array}{r}\text { Breast } \\
\text { screening }\end{array}$ & cancer \\
\hline $2014-2015$ & 4218 & 825 & & 432 & \\
\hline 2016 & 2186 & 447 & & 1595 & \\
\hline 2017 & 4156 & 601 & & 3992 & \\
\hline 2018 & 2489 & 199 & & 2629 & \\
\hline 2019 & 2062 & 69 & & 2110 & \\
\hline March 2020 & 422 & - & & 407 & \\
\hline
\end{tabular}

Source: 'Aisyiyah documentation, 2014-2020

Based on 'Aisyiyah's experiences, the behavior change approach involves complex factors and closely related to the culture of society, including values and beliefs of the individuals, groups, and society, especially issues concerning women's reproduction. A communication researcher emphasizes that behavior change is based on behaviorism - the external environment plays a more critical role in the behavior change than internal factors (Schiavo, 2019). To analyze how to integrate various factors encouraging behavior change so that women are willing to do screening to prevent cervical and breast cancers, the socio-ecological perspective model is fundamental. This theory relies not only on a single theory but also on various disciplines, such as sociology, psychology, and public health studies, analyzing interactions of people, community, and environment (Cancer Institute, n.d.). In the Indonesian context, family and community support approaches are crucial to strengthen behavior change communication to deal with breast and cervical cancers.

To analyze the approach taken in encouraging changes in health behavior by screening for early detection of cervical and breast cancers, the researchers used several theories as these behavior changes have occurred at the individual, group and community, and policy levels. At the individual level, the HBM model uses individual internal (personal) factors so that they are willing to make behavioral changes as recommended. Furthermore, the Integrated Model of Communication for Social Change (IMCFSC) introduced by Maria Elena and the Social Ecological Model (SEM) developed by UNICEF were used to analyze various approaches at various levels from individuals to society and policies.

The HBM is a concept that expresses reasons for individuals to willing or unwilling to perform healthy behaviors. The model can also be interpreted as a theoretical construct regarding individual 
beliefs in healthy behavior. Demographic characteristics such as socioeconomic status, education level, gender, age, and ethnicity are closely related to health prevention behaviors (Abraham, Sheeran, \& Henderson, 2011). Likewise, psychological factors, such as group factors and lifestyle factors, were also analyzed to determine individual perceptions and attitudes toward an issue, such as cervical and breast cancers. According to Savciuc and Timotin (2019), this theory aims to overcome personal barriers in adopting preventive behavior. The segmentation audience possibilities are the perceived susceptibility (of experiencing the risk of illness); perceived severity (consequences of an illness); perceived benefits (effectiveness of recommended behavior in reducing risk); costs or barriers in adopting behavior; motivations for action; and self-efficacy (self-confidence in the ability to act).

The Integrated Model of Communication for Social Change (IMCFSC) describes an interactive process where "community dialogue" and "collective action" work together to produce social change in a community that improves the health and welfare of all of its member (Figueroa, Kincaid, Rani, \& Lewis, 2002). This model explains that dialogue and action (behavior change) in the community are the processes carried out to solve problems. This process begins with recognizing problems and then identifies various parties and community leaders. An important step, in this case, is to clarify inaccurate perceptions. In behavior change cases, many myths and wrong perceptions develop in society, thus hindering behavior change. To achieve social changes, it must begin with changes at the individual level, namely knowledge, attitude, perceived risk, subjective norms, self-image, emotion, self-efficacy, social influence, and personal advocacy.

Social-ecological models describing interactive characteristics of individuals and environments underlying health outcomes have long been recommended to guide public health practice. This theory comprehensively analyzes health issues like promoting screening (early detection) of cervical and breast cancer issues. Ecological models assume that multiple levels of influence exist and that these levels are interactive and reinforcing (Golden \& Earp, 2012). The social, physical, and cultural aspects of an environment have a cumulative effect on health. This theory uses many levels to analyze behaviors, such as intrapersonal, interpersonal, institution, community, and policy. At the interpersonal level, the activities consist of education, training, skills enhancement of people who interact with the target population (family members, friends, teachers, coworkers), and modifications to home/family environments. At the policy level, the activities are education, training, skills enhancement of general community beyond the target population, and immediate contacts specific to policy change (UNICEF, 2015). This model also explores interpersonal change target intervention, namely perception or attitudes of social networks, the behavior of social networks, including the provision of social support and makeup of social networks.

This research, moreover, was also referring to some previous research of early detection for cancer conducted by Nwabichie et al. (2018), who examined the approach of effect and Health Belief Model (HBM) to promote cervical cancer screening in women group in Sisaket, Thailand. Other research was conducted by Maryam Johari and Ahmad Ali entitled Behavior Change Interventions in Breast and Cervical Cancer Screening Promotion using the Health Belief Model. These researches applied the HBM model theory of breast cancer issue. According to Savciuc and Timotin (2019), this theory aims to overcome personal barriers in adopting preventive behavior. The segmentation audience possibilities are the perceived susceptibility (of experiencing the risk of illness); perceived severity (consequences of an illness); perceived benefits (effectiveness of recommended behavior in reducing risk); costs or barriers in adopting behavior; motivations for action; and self-efficacy (self-confidence in the ability to act). In this research, the researcher did not only applied the HBM model to change the behavior of cancer early detection but applied more comprehensive theory such as The Integrated Model of Communication for Social Change introduced and Social Ecological Model (SEM) to support behavior change communication.

This study will contribute to health communication for behavior change related to the importance of a family and community approach in encouraging early detection of cancer. During this time, the medical service approach is still the dominant approach to support the early detection of cancer. In the context of Indonesian society as a communal society, the community and family approach has a strategic role in encouraging behavior change in health issues, particularly in cervix and breast cancer early detection. The level of knowledge and attitude towards the importance of early detection of cancer does not automatically lead to changes in individual behavior; this is where the significance is The Integrated Model of Communication for Social Change introduced and Social Ecological Model (SEM) as theory analysis. 


\section{METHOD}

This research aims to analyze community and family approaches to support screening (early detection) of cervical and breast cancers in some districts in Indonesia by Aisyiyah as a social organization. To get a direct understanding of the problems faced by the society, a comprehensive effort is required; one that does not separate the subject and object of research to produce broader knowledge and insight in interpreting social life (Salim, 2006). This study seeks to intrinsically understand the phenomena, regularities, and specificities of the studied cases (Salim, 2006). Referring to the approach developed by Dutta and De Souza (2008), a 'reflexive modernity' approach is needed in implementing health communication and campaign development. This theory emphasizes the need for research centered on participatory culture by examining social practices from multi-dimensional issues, such as reproductive health issues in society.

This research applied the case study method (Hollweck, 2016). A case study was used to comprehensively explain various aspects of a person, group, organization, program, or social situation. These aspects were researched, strived, and studied as profoundly as possible. The cases studied in this study include behavior changes in early detection of cervical and breast cancer, as well as community and family approaches in encouraging these behavior changes. To understand these cases, this research conducted an in-depth interview and document collection in the research area. The interview was carried out with the program coordinator, two organization board members, eight program staff at the national and local levels, 12 cadres as local leaders in communities, women as target groups in this program, and six religious leaders. In addition, the analyses of documents such as statistical data, periodic reports, and organizational documents were utilized in the triangulation method to obtain the validity of research results. This research was based on cases in some districts, namely Bantaeng, Mempawah, Sambas, Magelang, Lamongan, and Cirebon during 2015-2019.

\section{RESULT AND DISCUSSION}

Reproductive health remains a taboo topic discussed in the community, like in community and village meetings. Reproductive health issues are seen as a private problem and solely as a women's problem. Reproductive health problems have not become a priority in the development program. Therefore, to support access to reproductive health for women, it is crucial to develop strategies for cervical and breast cancers so that women perform the screening test.

Due to the high mortality rate of women from cervical and breast cancers, 'Aisyiyah has encouraged early detection of cervical cancer through Visual Inspection of Acetic Acid (IVA Test) and breast cancer conducted by the health worker. Before 'Aisyiyah began to promote early cancer detection intensively in 2014, the public was unaware of this issue. A few women knew about this early detection of cancer for the first time from reproductive health education at Balai Sakinah 'Aisyiyah (BSA). Although the government has launched a cervical cancer early detection movement in 2015 and socialization about early detection of cancer, the number of women carrying out early cancer detection remained small.

The assessment carried out by 'Aisyiyah before implementing the program developed three strategies: (1) strengthening women's leadership, (2) empowerment in the community, and (3) advocacy. This paper, however, focuses on two strategies, namely strengthening women's leadership and empowerment in the community. The strategy for strengthening women's leadership was carried out to increase the capacity and strategic role of women leaders in the community, such as 'Aisyiyah cadres at the sub-district level, village or Balai Sakinah Aisyiyah (BSA), and a community group.

The HBM, behavior change communication for social change approach, and SEM proved that behavior change in health issues started from the individual level, including knowledge, perception, and attitude. Knowledge intervention must be significant, as suggested by SEM. The individual should understand and have an awareness of a reproductive health issue. IVA and Pap-smear tests were new information for most women.

\section{Group Communication Method in Community}

At the individual level, knowledge, attitude, perceived risk, subjective norms, self-image, emotion, self-efficacy, social influence, and personal advocacy in behavior change, education, training, and skill enhancement were appropriate strategies. In most Indonesian communities, particularly in village areas, local leaders (health cadres) became agents for social change in health issues. In this case, 
women leaders had a strategic role in mobilizing empowerment through BSA as a forum for education, counseling, encouraging changes in reproductive health behavior, and strengthening other women's issues according to local environmental conditions. Moreover, cadres played a role in building communication with community leaders, religious leaders, health workers, and the village government to support reproductive rights fulfillment. Cadres' ability to build communication with these multi-stakeholders such as the community and religious leaders was vital; these stakeholders had significant cultural influence. Health workers had the competence in educating and providing access to early detection services, while the village government was the policymaker of development at the village level.

To disseminate information to women in the community, cadres have an important role as opinion leaders to provide information on new issues in the health sector, including early detection of cervical cancer and uterine cancer. As opinion leaders, cadres have the knowledge and ability to provide information that women trust in the community to encourage behavior change. The health information that has been obtained will be disseminated to women in the community. As communicators, cadres have a high confidence level (credibility) in educating about cervical and breast cancer prevention. The role of cadres at the community level, together with village midwives, building communication models, namely two-step flow communication, is still very significant. The development of social media does not necessarily cut off the role of cadres in educating the community. Women at the community level (village) entrust information to village cadres to get information about early detection of breast cancer and cervical cancer. Moreover, when it comes to early detection of cervical cancer and cervical cancer, cadre assistance is very much needed by women in the community.

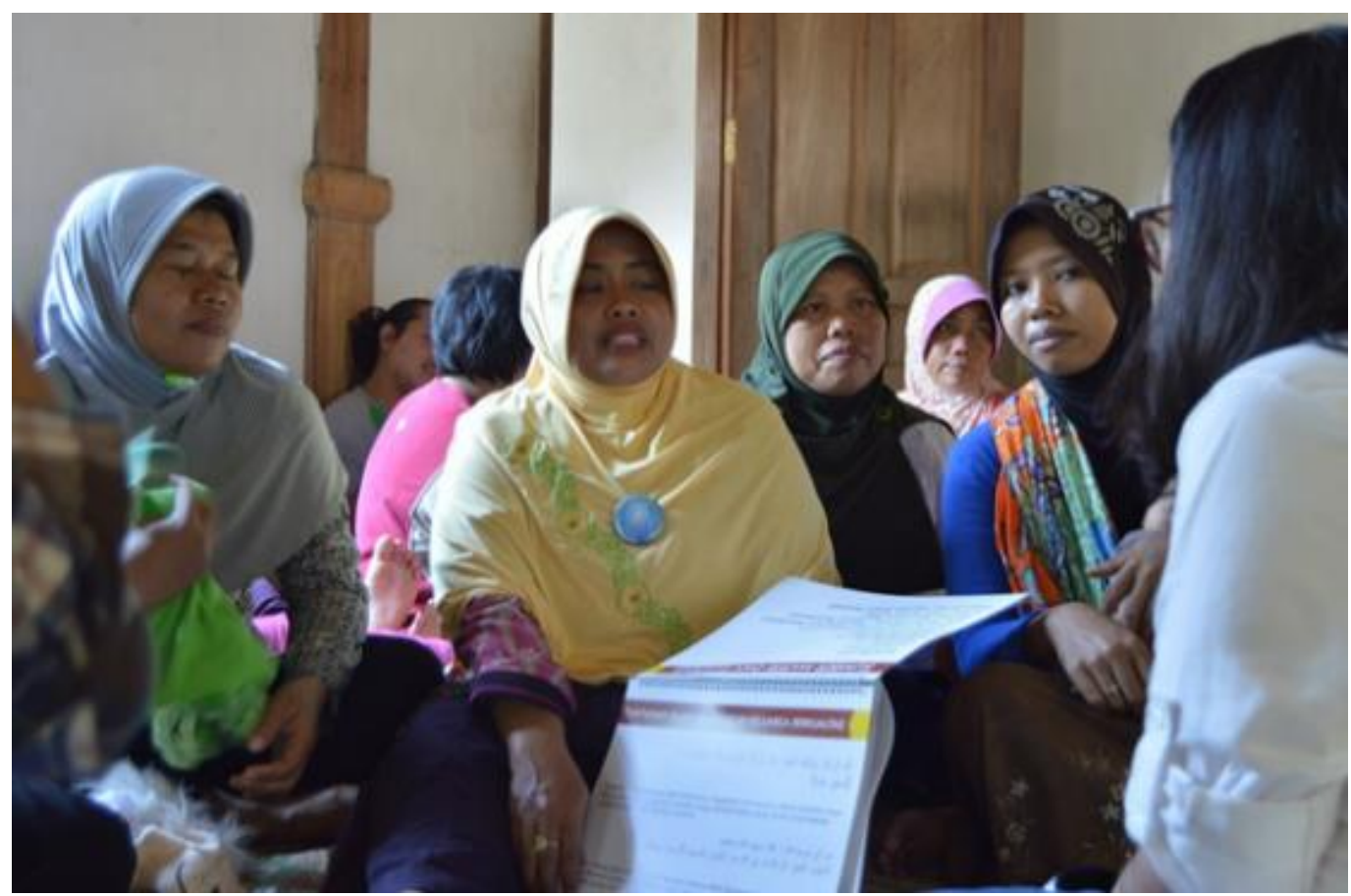

Figure 1. local leaders (health cadres) had a strategic role in mobilizing empowerment through BSA as a forum for education, counseling, encouraging changes in reproductive health behavior, and strengthening other women's issues according to local environmental conditions.

In Indonesian society, women have many groups for social activities. The groups in the community are created by the government, community, and social organizations. In this group community, disseminate information of health, social, sanitation, environment have done. Women hold regular meetings in the community either on a weekly or monthly basis. In Aisyiyah, socialization and education on various issues are carried out through the Balai Sakinah Aisyiyah at the village or community level. This group has members and administrators to carry out empowerment, education, and outreach, including encouraging women to carry out early detection of cervical and breast cancer. 
Regarding empowerment in the community, 'Aisyiyah educated women through Balai Sakinah Aisyiyah (women community group). This education process involved both health workers and cadres who are actively involved in education. Health workers were involved because they must conduct health outreach in the community, and they had competence in the health sector so that people could trust them. Even though they played a role in socializing health in the community, socialization was minimizing. Their tight schedules at the health facilities, lack of fund allocation for socialization, and lack of community forums to carry out socialization were the problems. Balai Sakinah 'Aisyiyah functioned as the basis for the reproductive health education group. Cadres, as agents in the community, were very helpful in improving public health. In this case, health workers could facilitate access to the early detection of cervical and breast cancers.

The prevention of cervical cancer through early detection in Balai Sakinah 'Aisyiyah provided members with information on the IVA and pap smear tests. Understanding the dangers of cervical cancer, risk factors for cervical cancer, and prevention through early detection of cancer was crucial in fostering the confidence of Balai Sakinah 'Aisyiyah members so that they were willing to do the IVA test. The approach through education for Balai Sakinah 'Aisyiyah members is in line with the HBM model, using individual internal (personal) factors so that they are willing to make behavioral changes as recommended. In Sambas, Mempawah, Cirebon, Magelang, and Bantaeng Districts, support to encourage women to do the IVA test was carried out by health workers before Balai Sakinah Aisyiyah existed. However, it was free, facilitated by primary health care (Puskesmas), and just a few women interested in doing the IVA test. In one village in Cirebon, for example, a BSA cadre said that before BSA was formed, primary health care had a free IVA test program and facilitated an ambulance for villagers who wanted to take the IVA test in primary health care. However, less than 15 women joined the program. It was different after 'Aisyiyah conducted socialization on early detection of cancer and encouraged women to undergo the IVA test, and collaborated with health workers to provide the IVA service. One hundred eleven women desired to carry out the IVA test, thereby increasing the number of women tested the IVA (interviewed with a cadre in Cirebon, 5 July 2020).

Likewise, in Sambas, West Kalimantan, health workers had difficulty getting women to do IVA tests; only a few conducted it. Nevertheless, after 'Aisyiyah gave education intensively and the cadre supported BSA members and other women in the community to do the IVA test, the number of women performing the test increased significantly. The same cases occurred in Mempawah District, West Kalimantan that primary health services and local health office staff put their trust in 'Aisyiyah and its cadres to carry out an early cancer detection program with local government funding. The success of 'Aisyiyah's cadre in educating women to make a change in behavior in the early detection of cancer in women was influenced by 'Aisyiyah's approach. 'Aisyiyah realized that changes in health behavior were influenced by many factors, not merely understanding. The increasing understanding of women about the importance of early detection of cancer did not always correlate with changes in behavior; in this context, it was the behavior of women to do IVA and breast cancer screening tests. Therefore, 'Aisyiyah used an educational approach in the community through groups, health education from a religious perspective involving religious leaders, a persuasive approach to BSA members, a family-based approach, and provided access to affordable cancer early detection services for rural communities.

What 'Aisyiyah has been doing by involving multi parties in the community to encourage early cervical cancer detection through the IVA test aligns with the Integrated Communication Model for Social Change (IMCFSC). They provide an interactive process through "community dialogue" and "collective action", work together to produce social change and increase community members' health status and welfare. The social ecology model was comprehensively used to analyze problems related to early cancer detection efforts. The social-ecological model showed that an environment's social, physical, and cultural aspects had a cumulative effect on health (Golden \& Earp, 2012). This statement was actualized by the leaders and cadres of 'Aisyiyah. In short, various approaches were used to encourage behavior change.

\section{Religious Values Messages: Behavior Changing}

In Indonesian society, religious values are a vital element to determine people's behavior; likewise, in health issues, especially reproductive health. 'Aisyiyah, as a religious-based organization, sees the importance of the involvement of religious leaders seen as influencing strengthening 
understanding and awareness from a religious perspective to encourage behavior change (Rochimah, Setyowati \& Rosemary, 2020). Niebroj (2006) stressed, that religion played and still plays in different cultures worldwide seems to prove the special position of religiously based convictions in relation to other politically, esthetical, or ethically based beliefs. Elementary knowledge of the history of mankind clearly demonstrates the fact that religions (understood as sets of beliefs and institutions) have been playing an extremely important role, and, in particular, have been able to significantly influence the political, ethical, and esthetical convictions.

In engaging religious leaders, 'Aisyiyah carried out capacity building for both male and female religious leaders regarding reproductive health and women's issues from progressive Islam, which became the basis for the Muhammadiyah movement. Capacity building for religious leaders was carried out through refreshment activities and dialogue with religious leaders on these issues, such as early detection of cancer, family planning, stunting prevention, and child marriage prevention, all from an Islamic perspective. Related to religious leaders' roles as part of community leader, RiveraHernandez (2015) explained that religious leaders are crucial in successfully delivering health promotion programs in Faith-Based Organization (FBOs). Religion can influence the way Mexicans deal with health issues. Faith-based organizations (FBOs) have been presented as effective channels for the delivery of health promotion and prevention programs. Religious leaders are community gatekeepers who can access community members and deliver information to health care providers and the congregation.

Based on 'Aisyiyah's experiences, most religious leaders welcomed this activity because they needed materials as a basis for delivering recitation. In their perceptions, the availability of reproductive health materials was still minimal, so that what 'Aisyiyah has done was sufficient to assist religious leaders in broadcasting reproductive health education. Particularly related to early detection of cancer, women and their families initially believed that cancer detection was unnecessary because they must open their genitals, causing women unwilling to do the IVA test. Delivering reproductive health issues in progressive Islamic perspectives was conveyed by 'Aisyiyah through religious leaders and newsletters and social media to reach the target group. Based on Aisyiyah's cases of roles of religious leader, increasing the religious leader's knowledge about breast cancer and cervical cancer and the importance of cancer early detection is important so that they have the necessary educational skills in the community. An understanding of the issue will be conveyed by a religious leader with religious values to encourage changes in women's behavior in doing cancer early detection. This model is similar to research done by Rivera-Hernandez (2015) in other issues that religious leaders need to get educated about diabetes and strengthened teamwork for partnerships with social and health care institutions to better serve the community. Pastors talked about how receiving education was very important when they were talking about their knowledge of Diabetes Mellitus. This case has a similar result with Niebroj (2006) that showed the role that religions not only play in history as a pure fact but also justify this fact. Health care must face the challenge of providing ethically acceptable medical treatment for patients belonging to different cultural (religious) traditions. Religious leaders, as an important element in the community, as agents to support behavior change communication in health issues, proved that Integrated Communication Model for Social Change (IMCFSC) applied.

\section{Gender Norms in Family: Applied Ecological Social Model}

Family decisions often influence health behavior-changing. Patriarchal culture places women as the secondary option. It means women must get approval from their husbands as the head of the family or other family members influential in each family. The decision control by the husband occurs even when the decision is related to the woman's body, such as during childbirth, birth control, or screening for cancer early detection. This research of health issues reinforced the research conducted by Kraft, Wilkins, Morales, Widyono, \& Middlestadt (2014) on child marriage that behavior change interventions to address social and structural factors, such as gender norms and inequalities, may be beneficial for effective program intervention. The most substantial evidence of effectiveness in controlled settings comes from interventions that seek to empower women to take actions to address health issues and from interventions that seek to empower adolescents and their families and to change community norms. The effectiveness of integrating gender in strategy making is designed to increase men's support for women's and children's health or to challenge gender norms that limit shared decision-making in domestic spheres. 
Gender is recognized as an essential social determinant of health. In many contexts, there is a structural disadvantage for a woman that goes beyond the fact of the illnesses affecting them. Nuanced gendered perceptions and health behaviors of both women and men play a significant role in women's ability to access the care they need. Men or older family members are often the decisionmakers for when and how women may gain access to healthcare (Ongtengco et al., 2020). In the context of early detection of cancer, before doing the IVA test, the wife usually requires permission from her husband. It is essential because one requirement before doing an IVA test is not having sexual intercourse three days before the test or a day before the Pap smear test. This requirement is because friction during sexual intercourse can cause blisters on the cervix, affecting screening quality. In addition, IVA screening is carried out in certain health facilities or public spaces that allow women to leave the house and coordinate with other family members related to home activities. Likewise, IVA is a health effort related to the early detection of cancer that can show negative or positive indications of IVA; that is, the presence of pre-cancerous lesions that can impact further health measures. Suppose a woman is indicated for positive IVA and require Cervical Cryotherapy to freeze tumor cells, pre-cancerous or cancerous. In that case, she needs to abstain from sexual intercourse for a long period of about one month. Therefore, the person need to communicate test/screening to their families, particularly their husbands.

The situation mentioned above shows the family's role in behavior change for the early detection of cancer, thereby requiring an approach to the family. In this case, 'Aisyiyah made the approach by educating families about reproductive health. After reproductive health education was carried out to their husbands, they responded favorably to this activity because husbands rarely received education on reproductive health. Through this activity, husbands understood the benefits of cancer early detection and were expected to support their wives in carrying out the IVA test. Apart from educating husbands, 'Aisyiyah also encouraged Balai Sakinah 'Aisyiyah members to communicate the information obtained to their families. At Balai Sakinah 'Aisyiyah, they were encouraged to have communication skills and the courage to speak.

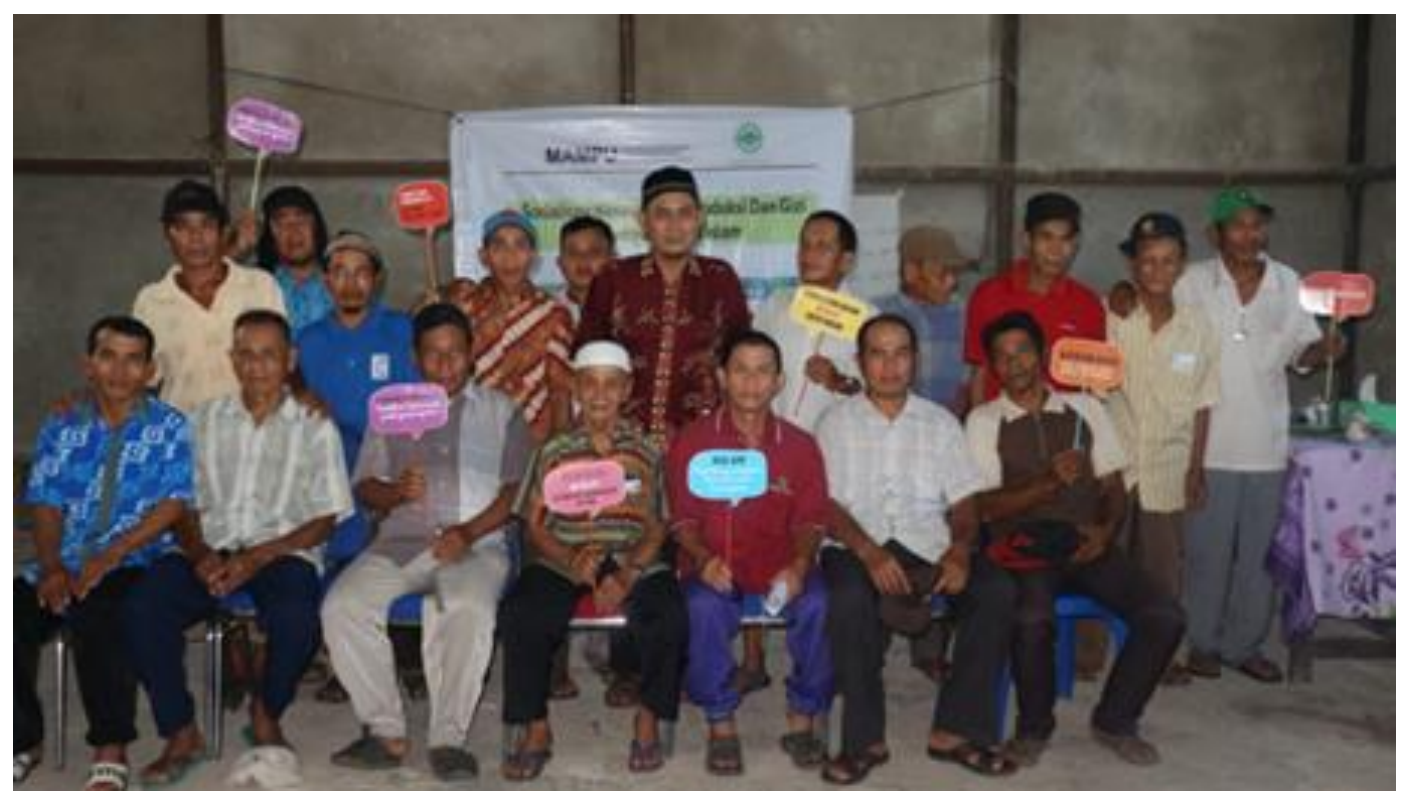

Figure 2. Reproductive Health Education for Husbands at Balai Sakinah `Aisyiyah

Through empowerment in Balai Sakinah 'Aisyiyah, cadres could also interact more intensely with other members and get to know the family conditions of BSA members to know the obstacles experienced by these members in carrying out the IVA test. In one village in Lamongan District, East Java, a BSA member could not take the IVA test because she had four young children and look after them herself. Understanding these conditions, cadres then took the initiative to share roles. A cadre took care of the children during the IVA test, and other cadres accompanied her to perform the test. In the case of supporting women cancer early detection, ecological models applied in this research, particularly in the cultural aspect (gender norm) of both equal relations between spouses and how to share domestic roles. A husband should be aware of and supported the wife to access reproductive 
health and share domestic roles. Social-ecological models assume that multiple levels of influence exist and that these levels are interactive and reinforcing. The social, physical, and cultural aspects of an environment have a cumulative effect on health. This theory uses many levels to analyze behaviors, such as intrapersonal, interpersonal, institution, community, and policy (Golden \& Earp, 2012).

\section{Communal Culture in Indonesia for Behavior Change}

Early detection of cancer is carried out through IVA test, namely by applying acetic acid to the surface of the cervix. After one minute of reaction, the results will be seen in the form of a color change in the cervical area smeared with acetic acid. To drop acetic acid on the cervix, a health worker needs to insert a speculum or duck tail into the vagina, which functions to hold the vaginal opening so that neck and cervix can be seen. Furthermore, the health worker will dip a cotton swab in a solution of acetic acid and apply it slowly to the surface of the cervix.

The IVA test process takes place in the cervix and requires the courage of a woman to do it. The concern is that if the IVA test result is positive or leads to cancer cases, many women are reluctant to do the test. "If I take the IVA test, I am worried if the disease will be discovered later," said a Balai Sakinah 'Aisyiyah member in one of the Magelang Districts. Monica, a companion of the Magelang PDA reproductive health empowerment program, agreed with this. According to Monica, the IVA test was a new thing for mothers because most women have just heard of the socialization about early detection of cancer through the IVA test from BSA. Meanwhile, from 'Aisyiyah Sambas, Lisa said that in Sajad Sub-district, Sambas District, several residents were reluctant to do the IVA test because they were afraid of knowing their disease and felt embarrassed (interviewed with program staff in Sambas, 1 July 2020).

In the context of cancer screening behavior, the construct called anxiety, fear, or worry remains the most extensively studied emotional variable. The model identified three discriminable sources of anxiety: (a) fear of screening components, (b) fear of screening outcomes, and (c) undifferentiated cancer fear. Referring to (Consedine, Adjei, Ramirez, \& McKiernan, 2008) reference, anxiety, fear, or worry factors happen in this case. The IVA screening process by opening the vagina makes some women feel embarrassed to do it, coupled with worries if the examination results are not as expected. 'Aisyiyah saw that the culture of Indonesian society was communal so that the IVA examination was carried out collectively or together as it could reduce shame and fear because many women carried out so that it became a form of support for fellow women. In addition, the factor of affordability was also a separate consideration for women who wanted to do an IVA test. The IVA screening conducted collectively could be conducted with funding from the village government or in collaboration with other parties to free residents of fees. Rochimah, Setyowati, and Rosemary (2020) mentioned that demographic characteristics, in this case, socioeconomic status and education level, influenced behavior patterns related to health efforts. The IVA test program that was held free of charge encouraged women to take the IVA test because they did not need to pay for the examination than cadres who urged BSA members to take the health facilities to test independently.

In Mamuju District, West Sulawesi, in one of 'Aisyiyah's programs, initially, both BSA members and women in the village were reluctant to take the IVA test. However, after one of the residents underwent an IVA test after claiming to have a complaint that matched the signs of cervical cancer, she was subsequently diagnosed with cervical cancer until she died. Only then did the community become aware of the dangers of cervical cancer, resulting in many women in the village decided to do the IVA test, held collectively. Several women conducting the IVA test said they felt relieved because they found out they were healthy. As mentioned by a member of the BSA in Sinoa Sub-district, Bantaeng District, she did the IVA test because she was worried about getting cancer, considering that she married at an age when her reproductive organs were immature. She received information that getting married before 21 or before the reproductive organs mature is a risk factor for cervical cancer. When she found out that the IVA screening result was negative, she was relieved.

As explained by Savciuc and Timotin (2019), disease prevention behavior such as early detection of cervical cancer can be encouraged when beneficiaries experience perceived vulnerabilities or risk factors, as in the case of a Bantaeng resident who felt worried because she married at a young age which is a risk factor of cervical cancer. In addition, perceived useful factors experienced by Balai Sakinah "Aisyiyah members carried out the IVA test could increase their confidence in the early detection of cancer. 
The cases of a husband not allowing his wife to carry out the IVA test not only occurred in Dukun Sub-district but also two other sub-districts in Magelang District. However, efforts of 'Aisyiyah cadres to overcome this obstacle by educating their husbands on community's health were quite successful. The wives were later able to perform the IVA test after educating her husband. "Husbands who initially did not allow permitted their wives after a health education meeting", Monica said. The understanding of religion as the husbands' argument prohibiting wives from taking the IVA test also occurred in Bantaeng, a village in Sinoa Sub-district. The husbands of several BSA members were followers of a religious sect with textual views to forbid wives to take the IVA test or other reproductive health efforts, including family planning. Even though the husbands still maintained their opinion to forbid their wives to take the IVA test, they promised not to provoke other husbands to do so.

Cadre, as a health volunteer, has a strategic role in the community. One of their roles is bridging roles. Volunteers involve community members by being connectors, signposting to services and information, and supporting people to improve their health. They are often embedded in the community and are already 'natural helpers'. As the results of our study, that cadres as volunteers also have a strategic role as bridging, as connectors to services related to access cancer early detection services, connectors to information about early detection, and supporting people to improve their health by encouraging women to do early detection of cancer (South, 2015).

Cadres are also "natural helpers" in the community. In the context of early cancer detection, cadres even helped women take them to the health service provider, and some were even willing to take care of the children so that their mothers could go to health services for early detection. When the woman was diagnosed with cancer, the volunteer also helped communicate to the family and assisted the person in accessing national health insurance to get cancer treatment.

Referring to research by Lu et al. (2012), the effectiveness of community-based or workplacebased group education programs increases when additional supports, such as assistance in scheduling/attending the screening and mobile screening services, are provided. The results of our study strengthen these findings. Those cadres in the community encourage women to carry out early detection of cancer by providing technical assistance, such as coordinating the schedule of early detection of cancer with health service providers and organizing the implementation of early detection of cancer in the community in collaboration with the health service provider.

Health workers at the primary health facilities often have difficulty reaching women for early detection of cancer. On the other hand, women do not know the schedule of early cancer detection services because, in some health facilities, early detection services are not available every day. In this context, cadres have a strategic role in mediating the relationship between the health workers and women as cadres live closer and interact more intensively with women in the community. In addition, in the Indonesian communal society, the implementation of collective early detection of cancer service organized by cadres in collaboration with local health service providers can overcome the concerns women experience when carrying out the test. They feel calmer because there are "friends" or fellow women who want to do early detection. They can share feelings with each other, such as feelings of fear when examined, and they can motivate each other to have courage when doing early detection.

\section{CONCLUSION}

Several conclusions were drawn based on the research results. First, in encouraging behavior change through communication, the culture, including religious interpretation, is a formidable challenge. Thus, the packaging of the messages by paying attention to cultural approach and a progressive religious perspective must be a key message in conducting intense socialization and education to encourage behavior changes related to early detection of breast and cervical cancer.

Second, religious leaders and cadres have an important role in encouraging behavior change, despite increasing communication channels such as social media. In this case, the two-step flow model of communication is still very significant in increasing awareness, knowledge, changing attitudes, and encouraging behavior change. The strong role of religious figures and cadres is influenced by the characteristics of the community, which are communal, and religious values are still the basis for determining the perspective, so that religious figures are credible opinion leaders as communicators. 
Third, gender norms in the family, such as that men are decision-makers so that women do not have a voice (muted group theory), are challenges in encouraging behavior change for early detection of cancer. Therefore, in the behavior change approach, the family approach needs to be a critical consideration, whereas the behavior change approach tends to use an individual approach so far.

\section{REFERENCES}

Abraham, C., Sheeran, P., \& Henderson, M. (2011). Extending social cognition models of health behaviour. Health Education Research, 26(4), 624-637. https://doi.org/10.1093/her/cyr018

Aras, R. (2011). Social marketing in healthcare. Australasian Medical Journal, Vol. 4, pp. 418-424. https://doi.org/10.4066/AMJ.2011.626

Cancer Institute, N. (n.d.). 11-0218 NCI Theory Book.1c.

Chichirez, C.-M., \& Assistant, P. (n.d.). Interpersonal communication in healthcare. In Journal of Medicine and Life (Vol. 11).

Consedine, N. S., Adjei, B. A., Ramirez, P. M., \& McKiernan, J. M. (2008). An object lesson: Source determines the relations that trait anxiety, prostate cancer worry, and screening fear hold with prostate screening frequency. Cancer Epidemiology Biomarkers and Prevention, 17(7), 1631-1639. https://doi.org/10.1158/1055-9965.EPI-07-2538

Dutta, M. J., \& De Souza, R. (2008, July). The past, present, and future of health development campaigns: Reflexivity and the critical-cultural approach. Health Communication, Vol. 23, pp. 326-339. https://doi.org/10.1080/10410230802229704

Figueroa, M. E., Kincaid, D. L., Rani, M., \& Lewis, G. (2002). Change on Integrated Model for Measuring the Process and Its Outcomes. The Rockefeller Foundation and Johns Hopkins University Center for Communication Program.

Golden, S. D., \& Earp, J. A. L. (2012). Social Ecological Approaches to Individuals and Their Contexts: Twenty Years of Health Education \& Behavior Health Promotion Interventions. Health Education and Behavior, 39(3), 364-372. https://doi.org/10.1177/1090198111418634

Hollweck, T. (2016). Robert K. Yin. (2014). Case Study Research Design and Methods (5th ed.). Thousand Oaks, CA: Sage. 282 pages. The Canadian Journal of Program Evaluation. https://doi.org/10.3138/cjpe.30.1.108

Johari, M., Eslami, A. A., Alahverdipoor, H., Hasanzade, A., \& Farid, F. (2014). Factors related to adopting healthy behaviors by patients with tuberculosis in Isfahan: Application of health belief model. Journal of Education and Health Promotion, 3(3), 86-86. https://doi.org/10.4103/2277-9531.139600

Jones, C. L., Jensen, J. D., Scherr, C. L., Brown, N. R., Christy, K., \& Weaver, J. (2015). The Health Belief Model as an Explanatory Framework in Communication Research: Exploring Parallel, Serial, and Moderated Mediation. Health Communication, 30(6), 566-576. https://doi.org/10.1080/10410236.2013.873363

Kraft, J. M., Wilkins, K. G., Morales, G. J., Widyono, M., \& Middlestadt, S. E. (2014, 13 May). An evidence review of gender-integrated interventions in reproductive and maternal-child health. Journal of Health Communication, Vol. 19, pp. 122-141. https://doi.org/10.1080/10810730.2014.918216

Lu, M., Moritz, S., Lorenzetti, D., Sykes, L., Straus, S., \& Quan, H. (2012). A systematic review of interventions to increase breast and cervical cancer screening uptake among Asian women. BMC Public Health, Vol. 12. https://doi.org/10.1186/1471-2458-12-413

Niebroj, L. (2006). The influence of religious beliefs on health care: Between medical futility and refusal of treatment National Standardization Program on Neonatological Practices and Procedures in Neonatology and Intensive Care View project THE INFLUENCE OF RELIGIOUS BELIEFS ON HEALTH CARE: BETWEEN MEDICAL FUTILITY AND REFUSAL OF TREATMENT. In Article in Journal of physiology and pharmacology: an official journal of the Polish Physiological Society. Retrieved from https://www.researchgate.net/publication/6724413

Nwabichie, C. C., Manaf, R. A., \& Ismail, S. B. (2018). Factors affecting uptake of cervical cancer screening among African Women in Klang Valley, Malaysia. Asian Pacific Journal of Cancer Prevention, 19(3), 825-831. https://doi.org/10.22034/APJCP.2018.19.3.825 
Ongtengco, N., Thiam, H., Collins, Z., de Jesus, E. Lou, Peterson, C. E., Wang, T., ... Dykens, J. A. (2020). Role of gender in perspectives of discrimination, stigma, and attitudes relative to cervical cancer in rural Sénégal. PLoS ONE, 15(4). https://doi.org/10.1371/journal.pone.0232291

Rivera-Hernandez, M. (2015). The Role of Religious Leaders in Health Promotion for Older Mexicans with Diabetes. Journal of Religion and Health, 54(1), 303-315. https://doi.org/10.1007/s10943-014-9829-z

Rochimah, THN; Setyowati, HN; Rosemary, R. (2020). Rumah Gizi `Aisyiyah: Komunikasi Kesehatan dengan Pendekatan Agama-Budaya. Komunikasi Global, 9(10), 141-161. Retrieved from http://www.jurnal.unsyiah.ac.id/JKG/article/view/16576/12489

Salim, A. (2006). Teori dan Paradigma Penelitian Sosial Buku sumber untuk penelitian kualitatif (Second Edition). PT Tiara Wacana.

Savciuc, O., \& Timotin, A. (2019). The Integration of Behavioural Change Models in Social Marketing Programs in Public Health. Marketing - from Information to Decision Journal, 2(1), 30-39. https://doi.org/10.2478/midj-2019-0003

Schiavo, R. (2019). Health Communication: From Theory to Practice (Second, Vol. 2). Publisher: San Francisco: Jossey-Bass, an imprint of Wiley.

South, J. (2015). A guide to community-centred approaches for health and well-being Full report. Retrieved from www.facebook.com/PublicHealthEngland

UNICEF. (2015). Communication for Development (C4D); MNCHN C4D Guide; Communication Strategy Guide for Maternal, Newborn, Child Health and Nutrition. 